\title{
From Colonial Reality to Poetic Truth: Baudelaire's Indian Ocean Poems
}

\author{
Meng Yuqiu
}

Department of French

School of European Languages and Cultures

Zhejiang International Studies University

Hangzhou, China

mengyuqiu@zisu.edu.cn

\begin{abstract}
Correcting the early Manichean interpretation of the abundant Baudelairian image of the black, later criticism tends to downplay the realist slavery framework and put emphasis on the psychological and philosophical dimension of the relationship between the master and the slave. My historicized analysis of "A une dame créole" uncovers evocations of slavery, violence and revolution in the vocabulary and imagery of the poem. By inscribing into the Ronsardian tradition a former French slave colony whose ruling elite never embraced revolutionary ideas, I argue, the poem puts the colonial enterprise into the perspective of France's nation building and problematizes both. The 1863 prose poem "La belle Dorothée" in which Baudelaire refers back again to his experience in the Mascarene Islands, exposes the crude nature of the French policy that pretended to give the slaves freedom while forced them to live in idleness, poverty or prostitution. If Baudelaire's oft discussed exoticism manifests a rejection of the society of his time, his longing for Africa and the Indian Ocean should not be dismissed as escapism.
\end{abstract}


Keywords: Slavery, Indian Ocean, Colonialism, Nation Building

In using the term "Indian Ocean poems" I follow the critic Françoise Lionnet in designating Baudelaire's poems, “À une dame créole" and "La belle Dorothée," both of which came directly from his youthful trip to the Indian Ocean. These two now canonical texts contain exotic imagery of which Baudelaire's work abounds. On the French side the poet's fascination with the so-called "black elements" is either viewed as an exotic eroticism, or as a means towards a spiritual and philosophical meditation. The postcolonial critics, mainly on the Anglo-American side, hasten to see lack of authenticity, lack of finesse, and confusion of diverse identities by the author. Against the two trends, Lionnet calls for attention to the importance of the historical and geographical specificities of the poems. In an 1998 essay using archival work she found on the islands of Mauritius and Réunion, Lionnet brought into focus the reality of Baudelaire's sojourn on the islands, and refuted mistakes made by critics such as Christopher Miller (1985) and Gayatri Spivak (1986) who neglected the specificity and missed Baudelaire's potential as a postcolonial writer. In a later essay “The Indies': Baudelaire's Colonial World” (2008) Lionnet enriches her argument along these lines, further indicating the urgent need to take into consideration the colonial context of Baudelaire's work. Although I agree with Lionnet about the importance of the context, her own cursory discussions of the texts themselves leave the poems' potential of interpretation largely unexplored.

Before I undertake close readings of the two poems, let me briefly trace Baudelaire's itinerary. In 1841 the nineteen-year-old Charles was sent on a trip for India, which his family had arranged with the hope to "change the course of his ideas, and to cure him of his wish to be an author" (Richardson, 61). Departing on board the Paquebot des mers du sud on June 9, Baudelaire landed on Mauritius on September 1. On September 19 the ship docked in Réunion, then called Île Bourbon. There Baudelaire became determined not to continue the 
voyage any more. On November 4 he boarded L'Alcide for France and arrived at Bordeaux on Februray 15, 1842. So much for his Eastern travel.

During his time on Mauritius Baudelaire stayed in the house of an advocate, GustaveAdolphe Autard de Bragard. On October 20, already on the island of Bourbon, Baudelaire sent his host a poem dedicated to the hostess, Emmelina Autard de Bragard. This poem, "À une dame créole," was first published in 1845, and later included in Les fleurs du mal.

À une dame créole

Au pays parfumé que le soleil caresse,

J'ai connu, sous un dais d'arbres tout empourprés

Et de palmiers d'où pleut sur les yeux la paresse,

Une dame créole aux charmes ignorés.

Son teint est pâle et chaud; la brune enchanteresse

A dans le cou des aires noblement maniérés;

Grande et svelte en marchant comme une chasseresse,

Son sourire est tranquille et ses yeux assurés.

Si vous alliez, Madame, au vrai pays de gloire,

Sur les bords de la Seine ou de la verte Loire,

Belle digne d'orner les antiques manoirs,

Vous feriez, à l'abri des ombreuses retraites,

Germer mille sonnets dans le cœur des poètes,

Que vous grands yeux rendraient plus soumis que vos noirs. 
The beginning of the poem seems innocuous at first glance, recalling the aroma, brightness and easiness of the island life. However, the islands history is already inscribed with the mention of trees ("arbres"). The island of Mauritius was "discovered" by the Portuguese in 1511, then became a Dutch possession in 1638. During their control the Dutch exploited the island mainly as a logging camp for ebony (Grove 132). Once the ebony seriously depleted, the island was abandoned in 1710. Another resource that the island was used for was amber (Vaughan 11). In fact, in the original version of the poem that Baudelaire sent to M. de Bragard in his letter of October 20, 1841, the verse was "J'ai vu dans un retrait de tamarins ambrés" (Lionnet 1998, 69). The final version's “empourprés” manages to keep the phonetic similarity with "ambrés."

Verse five has been amply commented on. Although critics notice the play of a series of shades from white to black, and talk about ambiguities, I have not yet seen anyone realize how important the term "teint" is. I want to point out that this is the key word in the poem's economy. Its meaning gets instantly transformed if we put it in the framework of racial connotations. Miller rightly reads the ambivalence that exists in the phrase "brune enchanteresse," without going far enough in the larger context of racial discourse (Miller 101). When the French seized the island in 1715, they continued the Dutch practice of importing slaves from mainland Africa and Madagascar. In a society that had had a history of slavery and racial mixture, one's skin color has primordial importance for one's social status. Because of mixed marriage and more frequently, concubinage and sexual exploitation such as prostitution and rape, the population of the island is extremely diverse as far as skin hue is concerned. The white ruling class had an acute anxiety over racial purity. For them the "color" of skin, categorized as black or white, had grown insufficient as a signifier of racial identity. By contrast, the "tone" of the skin, offering a wide spectrum of nuances from lily white to ebony black, became a more valid term, sustained by a dazzling hierarchy. What is 
more, the word "teint" is also the past participle of the verb "teindre", to "color". Since, according to the racial discourse of the time, even "one drop of black blood" can taint a white lineage, then every "tone" is potentially "tainted" before proved otherwise. Thus the at once "pale" and "warm" "tone" of the lady establishes a deliberate indeterminacy, even if she is more likely a white person with black hair who is enchanting, with "brune" as a noun and "enchanteresse" as an adjective, rather than a dark-skinned enchanter, with "brune" as an adjective and "enchanteresse" as a noun.

While it is easy to perceive the evocation of the goddess Diane the Huntress in the figure of the tall and slim lady, I want to remind readers that the idea of hunting has a distinctive meaning on the island, that of chasing, trapping and catching runaway slaves, the maroons. "La chasse aux marrons" had been a large part of life on the island. Plus, the word "marchant" points to its homophone "marchand." During the epoch of slavering, slave traders were called "marchands d'hommes." The Creole lady with her "tranquil smile" and "confident eyes", then, suddenly presents a disquieting image incongruent with the conventional peaceful insular life that the beginning of the poem seems to suggest.

Ernest Prarond, life-long friend of Baudelaire, wrote to Eugène Crépet, the poet's first biographer:

“A-t-il poussé son voyage plus loin? Je ne le crois pas. Il est certain que L'Albatros lui fut suggéré par un incident de sa traverse. Il nous le récita dès son retour. A part cette pièce et le souvenir d'une négresse ou malabare, suivant une expression, je crois, de l'île Maurice, qu'il avait vu fouetter à l'île Maurice, tout le journal de sa pénitence maritime semblait page blanche."

(Dayre and Pichois, 76-77)

According to Prarond, then, the young Baudelaire witnessed the cruel reality of a society with social and racial oppression. With slavery being abolished on Mauritius in 1835, the black woman was no longer supposed to be a slave. She was nevertheless whipped, and 
apparently in public. The experience seemed to have marked Baudelaire, since the latter singled it out to his friends.

To what extent should we trust the authenticity of this anecdote? It could be a real life experience, or, just a literary reminiscence. I want to remind my readers of the passage in Voyage à l'île de France, in which Bernardin de Saint-Pierre tells his encounter with a Creole lady, a Mme de V..., who whipped a female maroon. The text is worth quoting at length:

Après avoir marché deux lieues, nous vîmes sur une hauteur une belle maison de pierre. Je m’y arrêtai pour m’y reposer: elle appartenait à un riche habitant appelé la V... Il était absent. Sa femme était une grande Créole sèche, qui allait nu-pieds suivant l'usage du canton. [...] Mme de la V... y posa en faction une Négresse nue, qui n'avait pour tout habit qu'une mauvaise jupe. Je demandai à passer le temps de la chaleur. [...] Mme de la V...tenait à la main une queue de raie épineuse: elle en lâcha un coup sur les épaules nues de l'esclave qui en furent marquées d'une longue taillade, et un revers sur le mâtin qui s'enfuit en hurlant.

Cette dame me conta qu'elle [...] allait dans les bois, à la chasse des Noirs marrons ; elle s'en faisait honneur [...]

A quatre heures après midi, je quittai cette Bellonne qui chaissait aux hommes ; [...]

(Bernardin de Saint-Pierre 169)

The nudity of the female body, the sexually charged terms like the "tail" ("queue") that "released" ("lâcha") a "blow" ("coup") contain thinly veiled discourse of sexual violence. Bernardin was so deeply disturbed by the gender of the attacker, that when he transformed the real life incident into the pivotal episode of his novel Paul et Virginie, he felt the need to suppress the "gender disorder" by turning the owner into a man. Whether the young poet traveler really saw a negresse being beaten with his own eyes or appropriated Bernardin de Saint-Pierre's account as his own, does not matter that much. Bernardin's account makes the 
image historically viable. If Baudelaire did see a similar scene, it only reinforces the fact that the cruel practice was still in use, seventy years after. If Baudelaire did not see it but took inspiration from Bernardin, then we can say the repressed female slave owner in Bernardin finds her way into Baudelaire's poetry. This reading brings out elements of violence that would otherwise be "ignored". The color "pourpre" of the bunch of trees under which the lady lies resembles that of blood. This deep-red, almost black blood, recalls the blood shed during colonial rule. The leaves, seemlingly soaked in blood ("empourprés"), darken the lady's face and make her skin tone look "warm" or even "brown".

From this perspective, the inscription into the Ronsardian tradition of the second half of the poem becomes problematic. The present conditional "Si vous alliez... vous feriez" makes the claim temporally inappropriate. Eve Célia Morisi is certainly right in saying that the combination of the "mode courtois" and "éléments étrangers" "métisse le texte" (Morisi 553). We have a modern "Belle dame sans merci," only, those she tames with her eyes are no longer poet lovers, but blacks. In 1810 the British took both Île de France and Île Bourbon, in 1814 they returned Île Bourbon to France but kept the other island, changed its name back to Mauritius and abolished slavery on it in 1835. Therefore, in 1841 when Baudelaire visited, Mauritius was a British colony using indentured laborers from India together with enfranchised slaves and their descendants. The Franco-Mauritians such as Baudelaire's hosts, rapidly becoming a minority among the island's population, clung to their past as French ruling on a French colony (Lionnet 1998, 71). The cruel irony is that, had the Creole lady been physically in France, she would probably not have survived the Revolution: after all, the "neck" ("cou") was the part of the human body from where the real nobility had its head chopped off, both symbolically with the kill of the king, and concretely with the falling of so many noble heads. The invitation to "vrai pays de gloire" is thus sarcastic: France's 1830 annexation of Algeria was sure driven by the pursuit of national pride and "glory". By 
inscribing into the Ronsardian tradition a former French slavery colony whose ruling elite never embraced revolutionary ideas, the poem puts the colonial enterprise into the perspective of France's nation building and problematizes both.

It is the poem itself that is "maniéré" then. But it is a self-conscious manierism. In the imagery of "vous feriez [...] germer mille sonnets dans le cœur des poètes," the verb "germer", to engender, contains the word "germe" — germ. Plus it performs a malicious word play on the French words "ver" — worm and "vers" — verse. Therefore, the line ends up suggesting the macabre image of thousands of worms sprouting from the poets' hearts.

It is interesting to observe critics mistake the lady in question for Jeanne Duval. A Baudelaire critic, Jacques Crépet, invented a genealogy for Jeanne Duval:

En voilà assez, je crois, pour expliquer les tristes hérédités qu'accusa l'amie de Baudelaire, Jeanne Duval, alias Jeanne Lemer, selon toute vraisemblance la fille de la Jeanne Lemaire, inhumée à Belleville, et la petite-fille de la prostituée nantaise Marie Duval - et aussi comment un peu de sang noir pouvait être venu teinter les épaules grasses de la "noble enchanteresse".

(Richon 16. Emphasis mine)

The genealogy was pure invention without foundation. What is significant here, I think, is the link that the critic makes between black blood, tainted skin tone and Jeanne Duval. By applying the phrase "noble enchanteresse" to Jeanne Duval, the critic allows the supposed mixed-blood take on the characteristics of the white day, making life imitate art.

The problem of slavery continued to preoccupy Baudelaire, his relating the oppressed status of slave to that of the poor and even the artist is in the footsteps of Marceline Desbordes-Valmore who makes common cause the fate of slave and that of the proletariat, and George Sand, who advocates women's and slaves' liberation. The correspondence between Baudelaire and Hugo over the poem "Le cygne" (1860) shows their attitude towards the slavery issue in the United States concerning the death of John Brown. It is in this spirit 
that should be read the 1863 prose poem "La belle Dorothée" in which Baudelaire refers back again to his experience in the Mascarene Islands, during which the first version of it was written (Pichois 1119). Compared to the obsolete way of thinking and living of the elite class on Mauritius, the even more reactionary Réunion repulsed the young Baudelaire. As Lionnet has shown, Baudelaire denied he had ever put foot on the island, because of the sense of humiliation and suspicion he felt from the local elite. During his stay he did nothing other than "frequenting black prostitutes and writing" (Lionnet 1998, 68). The beautiful Dorothée comes out of his contact and memory of the island's prostitutes.

The prose poem reads in antipode with "À une dame créole.” Whereas the Creole lady, former slave owner, lives a leisured life in pseudo-noble manners, the black prostitute busies herself as a sex slave. I do not agree with critics who view Dorothée as a typical figure of colonial mimicry. If the sonnet debases the lady while seeming to elevate her (Miller 106; Morisi 554), the prose poem celebrates a colonial subject defying her subjugation.

Central to a sociopolitical understanding of the poem is the mention that Dorothée is "affranchie". This puts into focus the chronological transfer of the poem, because in 1841 when Baudelaire was on Bourbon, slavery was still in vigor on the island, in contrast with the situation in Mauritius. It is only after the 1848 Revolution that slavery was finally abolished all over the French empire. In Réunion, although the abolition of slavery was not the result of a popular insurrection, this formidable social transformation was not as peaceful as many historians have claimed (Vergès 69). Emancipation proved to bring unexpected consequences that had altogether escaped the imagination of metropolitan and colonial republicans. To the French republic, these excluded citizens remained in the domain of the unthinkable, of the inconceivable.

In 1848 Baudelaire took part in the February insurrection and afterwards "fut pris d'un accès de démocratisme ardent; il fréquenta les Sociétés populaires", so Julien Lemer 
was to recall, "et je ne sais pas trop si, pendant quelque temps, l'impeccable Théo[phile] Gautier ne fut pas remplacé dans ses admirations par l'impeccable P.-J. Proudhon." (Richardson 406). The Revolution of 1848 brought disillusionment to many high democratic hopes in France and its colonies. In the 1863 poem Baudelaire exposed the crude nature of the French policy that pretended to give the slaves freedom while forced them to live in idleness, poverty or prostitution. Such a critique is undertaken through the dynamics of the notions of "affranchie", "libre" and "racheter". The poem stages the difference between "freed" and "free" in the phrase "bien qu'elle soit libre." The subjunctive mode of the verb "to be" emphasizes the adjective's instability. Dorothée has to labor, "elle était obligée d'entasser, piastre sur piastre pour racheter sa petite sœur" because "le maitre de l'enfant est si avare, trop avare pour comprendre une autre beauté que celle des écus!" The verb "racheter" is of primordial importance here, for Baudelaire reveals a truth that the rhetoric of the French colonial discourse tries to conceal. Ever from the sixteenth century the monarchy defined franchised as being "bought" ("acheter"). However, it is clear in the poem that being bought does not bring any liberty. The big sister Dorothée has to "buy back" ("racheter") her little sister from the exploitive master. Dorothée is d'or ôtée (Sicard-Cowan 543), to be ripped off gold. The "gold" she accumulates with the sale of her body will be "ripped off" by the greedy master.

Especially, no matter how hard one tries, the state of being "affranchi" can never equal that of being franc, that is, French. The link between the character of being franc and that of being French has its origin in the first Germanic tribe that lived on the territory that became France, les Franks. The relationship of the Gauls and the Franks constituted the focus of the foundation of modern France. Ever since the sixteenth century the monarchy tried to establish the legitimacy of a France as a modern nation state. As Trouillot tells us, to see the state as "the only legitimate container was first proposed in most vigorous terms by the 
government of the Franks under Francis I" (Trouillot 84). In the domain of literature, the literati, supported by the court, also contributed to the process. The Pléiade especially made efforts to acclimate the Petrarchian tradition. Du Bellay's Défence et illustration de la langue française made multiple mentions of the link between franc and français.

The mention of some French military officer as Dorothée's potential client is not fortuitous. Lurking in the background is France the metropole, who construed an image of the colonies as a place of sexual and economic libertinage (Garraway 2005). In metropolitan France's imagination, the vagrant, the women prostitutes were "primitive rebels" whose existence and ways of living were reminders of the failure of hegemonic social control: they worked only enough to survive, contesting the principles on which capitalism was based: work, discipline, and private property. The poem subverts this ideology by presenting Dorothée as the one who moves forward (“elle s'avance... elle s'avance ainsi”), negating colonial discourse's judgment of the indigenous for being backward. Walking barefoot ("elle marche sans souliers"), Dorothée refuses the signifier of freedom imposed by the whites. This sham freedom is further ridiculed by the last part of the poem which ends with the sound /ky/ ("écus" $\rightarrow$ "et cul"), exposing the sordid nature of living the former slaves were forced into by the so-called emancipation.

Dorothée sells her body towards a reunion with her sister. The island's name, La Réunion, then, serves as an irony for the situation. It was in 1793 that the Convention changed the island's old name, Ile Bourbon, to La Réunion, to commemorate the reunion of the National Guard with the Assembly. The Restoration restored the island's name to Ile Bourbon. Following the 1848 Revolution, the island's name changed yet another time to La Réunion. The solidatarity between Dorothée and her sister constitutes a sorority, problematizing the republican dream of universal fraternity enmeshed with French imperial hegemony and ethnocentrism (Wahnich 356). 
Thus, I view this poem as a critique of the 1848 Revolution whose abolition of slavery failed to bring about liberation, in the same way domestically it had only an appearance of a revolution that delivered but a short lived Third Republic giving away to the Second Empire. In this respect the Baudelairian text is complementary to direct representations of the 1848 Revolution found in his contemporary authors such as Flaubert.

In sum, the abundant Baudelairian image of the black can be grasped neither as a simplistic Manichaeism nor an abstract philosophical relationship between the master and the slave. His early encounter with slavery as an institution in the French Indian Ocean colonies was real and important for his poetics. If Baudelaire's oft discussed exoticism manifests a rejection of the society of his time, his longing for Africa and the Indian Ocean should not be dismissed as escapism. Far from being just "flirtations with the exotic" (Sharpley-Whiting 62), the Indian Ocean poems "loop back on [themselves] to critique the colonial ideology it rehearses" (Lionnet 2008, 728). 


\section{References}

Dayre Emile, and Claude Pichois. La jeunesse de Baudelaire vue par ses amis. W. T. Bandy Center for Baudelaire Studies, Vanderbilt University, 1991.

Garraway, Doris. The Libertine Colony. Duke UP, 2005.

Grove, Richard. Green Imperialism. Cambridge UP, 1995.

Lionnet, Françoise. "Reframing Baudelaire: Literary History, Biography, Postcolonial Theory, and Vernacular Languages.” Diacritics 28, no. 3 (1998): 63-85.

—_." “The Indies”: Baudelaire's Colonial World.” PMLA 123, no. 3 (2008): 723-736.

Miller, Christopher. The Blank Darkness: Africanist Discourse in French. The University of Chicago Press, 1985.

Morisi, Eve Célia. ““À une dame créole’ de Charles Baudelaire: de l'ambiguïté colonialiste à l'ambiguïté plurielle," Nineteen-Century French Studies 35 (2007): 547-557.

Pichois, Claude. Ed. Baudelaire, Oeuvres completes. Gallimard, 1975.

Richardson, Joanna. “Dr. Melchior Yvan: An Influence on Baudelaire?” French Studies 46 (1992): 406-411.

Richon, Emmanuel. Jeanne Duval et Charles Baudelaire: Belle d'abondon. L'Harmattan, 1999.

Saint-Pierre, Bernardin de. Voyage à l'île de France. La Découverte, 1983.

Sicard-Cowan, Hélène. “Désir colonial et 'conscience historique authentique': 'La belle Dorothée' de Charles Baudelaire,” Nineteen-Century French Studies 35 (2007), 537546.

Spivak, Gayatri, “Imperialism and Sexual Difference," Oxford Literary Review 8 (1986): 226-40.

Trouillot, Michel-Rolph . Global Transformations. Palgrave, 2003.

Wahnich, Sophie. L’impossible citoyen. Albin Michel, 1997. 
Vaughan, Megan. Creating the Creole Island: Slavery in Eighteenth-Century Mauritius. Duke UP, 2005.

Vergès, Françoise. Monsters and Revolutionaries. Duke UP, 1999. 